\title{
DETERMINING THE GAMIFICATION USER TYPES OF GIFTED CHILDREN AND THEIR PARENTS, AND EXAMINING THEM IN TERMS OF MOTIVATION
}

\author{
Senay Kocakoyun Aydogan ${ }^{1 *}$, Aslan Aydogan ${ }^{2}$ \\ ${ }^{1} \mathrm{PhD}$ Candidate, Istanbul Gedik University, Turkey, senay.aydogan@gedik.edu.tr \\ ${ }^{2}$ PhD Candidate, Istanbul Gedik University, Turkey, aslan.aydogan@gedik.edu.tr \\ ${ }^{*}$ Corresponding Author
}

\begin{abstract}
The types of users in gamification systems are identified as Socialisers, Free Spirits, Achievers, Philanthropists, Players, and Disruptors. Socialisers, Free Spirits, Achievers, and Philanthropists are more internally motivated; the motivation of the players is external. In gamification systems, different game mechanics motivate users in different directions. In explaining the different user types that exist in gamification systems and the characteristics that determine them, it is necessary to identify the user types of the gifted children and their parents and to reveal the sources of motivation. Therefore, the general purpose of this study is to examine the gamification user types Hexad of gifted children and their parents' players in terms of motivation sources. In the study, the descriptive research method which is one of the quantitative research methods was adopted. The sample of the study consists of 21 gifted children and their parents who are enrolled in the Children's University in the fall semester of 2019-2020. In order to determine the type of players/users in gamification, "The Gamification User Types Hexad Scale" was applied online. Research findings revealed that the most common user types in gifted children's environments were, Achievers and Free Spirits, followed by less average Philanthropists and Socialisers, and the least seen user type was Players. The results of the study revealed that gifted children have phones from the age of 8 . It was also concluded that the majority of gifted students had computers. It was determined that the majority of those who had computers were Achiever and Free Spirit and those without computers were Socialiser and Philanthropist. It was concluded that the majority of parents did not play digital games. Mothers who do not play digital games are identified as Philanthropist, Socialiser, and fathers who do not play digital games are Achiever and Philanthropist.
\end{abstract}

Keywords: Gifted children, parents, gamification, user types, player types, motivation.

\section{INTRODUCTION}

Personal differences have an impact on learning capacity. Children with personal differences can get ahead of their peers and provide efficiency to the society in which they live, such as education, art, science, and technology. These children who have the potential to bring the countries in which they live in better places in the future are called "gifted children" (Bayraktar, 2001). Many studies have identified gifted children in different ways. According to Renzulli (1986), giftedness is innate skills and behaviors. Renzulli; he states that IQ means nothing for gifted children and that gifted children need to demonstrate high levels of responsibility, innovation, and creativity. Science and Art Center (BILSEM) Directive; It is defined gifted children as individuals with high leadership capacity, more successful in private academic fields than their peers, and performing superior in the fields of art, intelligence, and creativity (MEB, 2001).According to the definitions obtained from the studies, giftedness; can be expressed as a state of higher than normal development and a high level of mental capacity. Gifted children are individuals who creative (Torrance \& Goff, 1989), selfregulated learners (Risemberg \& Zimmerman, 1992), have a wide range of imagination (Freeman, 2003), learn fast (Winebrenner, 2003), have problem-solving skills (Sak \& Maker, 2005). In addition, they are 
individuals who can think flexibly (VanTassel-Baska, 1994), curious (Blackburn \& Erickson, 1986), learn quickly without the need for practice and repetition (Freeman, 2004), and they can use inquiring learning approaches (Winebrenner \& Brulles, 2009). These qualities of gifted children can be effective in many areas in learning with the right motivation. One of the areas that contribute to motivation is gamification systems.

Zicherman and Cunningham (2011) are defined as gamification as problem-solving and attracting users' attention. Gamification describes as 'use of the game design of non-game content' (Deterding, Dixon, Khaled, \& Nacke, 2011; Werbach \& Hunter, 2012). One of the noteworthy points in the definition of gamification reflects the aim of gamification. According to Deterding (2012) and Deterding, Dixon, Khaled, \& Nacke (2011), the main idea of gamification is to motivate desired behaviors by using game design elements in non-game contexts, products or services. Motivation is the basic element of gamification design and behaviors that arise or change with this motivation (Hamari, 2013). In order to create more effective gamification designs, it is necessary to know which theoretical foundations are based on gamification. In this context, when the behavior model is examined, it is understood the importance of motivation in changing behavior (Fogg, 2009).

Self-determination Theory: Motivation; it is described as the power that affects the individual internally and externally positively or negatively (Ryan, Rigby \& Przybylski, 2006). Intrinsic motivation is related to the person himself (self-directed), and extrinsic motivation is the type of motivation that is completely outside the world (Zicherman \& Cunningham 2011). The concept of motivation can be taken as the basis for successful learning and teaching (Çakmak \& Ercan, 2006; Wild \& Hawkins,1992). Motivation is understood by what stimulates the behavior and the source of continuation (Ames, 1992). Motivation is the direction of the person towards the aim and the power to strive towards that goal. In other words, it is a situation where more than one person makes continuous efforts towards a certain purpose (Ersen, 1997). Gamification expert Marczewski (2018) has determined which game mechanics can motivate which player type. Player Types: is defined as the classification of gamification users as a result of having different user motivations in interaction with gamified applications (Marczewski, 2018; Tondello, Mora, Marczewski \& Nacke, 2018). Marczewski (2018) divided the player types into six parts according to the level of internal or external motivation of the users. What distinguishes this classification from the other is that this classification was created for gamification systems (Marczewski, 2018). The types of players (Gamification User Types Hexad) in gamification systems and game mechanics which can motivate player type are summarized below (Marczewski, 2018).

- Socialisers: They are motivated by relatedness. The sources of motivation are to communicate with others by establishing social relationships in gamification systems. Gamification Elements; Guilds / Teams, Social Network, Social Discovery, Social Status, Social Pressure, and Competition.

- Free Spirits: They are motivated by autonomy. Sources of motivation are creating new things or discovering new places. Gamification Elements; Exploration, Branching Choices, Easter Eggs, Unlockables, Creativity Tools and Customisation.

- Achievers: They are motivated by competence. They are open to learning new things and improving themselves. Gamification Elements; Challenges, Certificates, Learning, Quests, Levels/Progression, Boss Battles.

- Philanthropists: They are motivated by purpose. Even though there is no reward at the end of what they do, they want to help other people in everything, and what attracts them is that they are beneficial to people. Gamification Elements; Altruistic Purpose, Care Taking, Access, Collection, Gifting / Sharing, Knowledge Share.

- Players: They are motivated by extrinsic rewards. They fulfill all the required tasks in the case of the reward they will receive from the system. Gamification Elements; Points, Prizes, Leaderboards, Badges, Virtual Economy, Lottery.

- Disruptors: They are motivated by the triggering of change. They desire a constant change and try to change the system by linking the source of motivation for the change of the system. Gamification Elements; Innovation Platform, Voting, Development Tools, Anonymity, Light Touch and Anarchy.

Socialisers, Free Spirits, Achievers, and Philanthropists are more internally motivated; The motivation of the Players is external. The source of motivation for the types of internally motivated users is related to the autonomy, competence, relevance in the Self-Determination Theory (Marczewski, 2018). Tondello et al. (2018) conducted research on the changing motivations of individuals and the different effects of gamification on individuals regarding the characteristics or characteristics of users. They also argued that gamification users have different user motivations in their interaction with gamified applications and that the 
separation of these player types is essential for successful gamification systems (Tondello et al., 2018). But; parents who are unaware of such varying sources of the motivation of player types think that they will motivate their children according to their own truths and desires. It keeps the child away from the happy and successful environment and unwittingly directs the child to an unhappy and unsuccessful environment. Therefore, in this study, it is aimed to determine the actor types of their gifted children and their parents. The aim is to enable them to recognize the sources of the motivation of the player types and to help the real potential of gifted children. For this reason, the gifted students and their parents' player types were examined in terms of motivation sources. After learning the results of the player types scale 'How did learning your player types affect you?' research question was asked. Therefore, it is thought that identifying the existing player types in the adaptation of gamification as a solution to increase the motivation of gifted students and their parents to similar educational systems will help this process and give insight to those who work in this field.

\section{METHODOLOGY}

\subsection{Participants}

The study group of the study consists of gifted children and their parents attending Children's University in 2019-2020 in the fall term. A total of 21 gifted children and their parents contributed to the study.

\subsection{Instruments}

In this study, a validated and reliable scale was used and the interview form was used to determine the views of the parents. This scale is the "The Gamification User Types Hexad Scale" (Tondello et al., 2016). "The Gamification User Types Hexad Scale" was developed by Marczewski (2015) in view of the user types designed specifically for gamification (Tondello et al., 2016). Researchers developed a 24-item questionnaire response scale to score six different motivational user preferences within the framework of Marczewski's user types for gamification. In the 7-point Likert-type scale, all four items are associated with one user type in gamification. For the internal validity of the scale, the Cronbach Alpha coefficient of each user type was analyzed separately. The reliability coefficients $(\alpha)$ given for each user type in this measurement tool are given in Table 1 (Tondello et al., 2016).

Table 1. "The Gamification User Types Hexad Scale" internal scale reliability

\begin{tabular}{|l|c|}
\hline User Types & Cronbach Alpha Coefficient \\
\hline Philanthropist & 0.89 \\
\hline Socialiser & 0.83 \\
\hline Free Spirit & 0.72 \\
\hline Achiever & 0.75 \\
\hline Disruptor & 0.73 \\
\hline Player & 0.69 \\
\hline
\end{tabular}

Table 2 shows the test-retest reliability analysis results measured by Pearson $r$ for each user type.

Table 2. "The Gamification User Types Hexad Scale" Test-retest reliability (Tondello et al., 2016)

\begin{tabular}{|l|c|}
\hline User Types & Pearson correlation coefficients \\
\hline Philanthropist & $.85^{\star \star}$ \\
\hline Socialiser & $.85^{\star \star}$ \\
\hline Free Spirit & $.63^{\star *}$ \\
\hline Achiever & $.79^{\star \star}$ \\
\hline Disruptor & $.78^{\star *}$ \\
\hline Player & $.35^{\star}$ \\
\hline
\end{tabular}

${ }^{*} p<0.05 .{ }^{* *} p<0.01$.

The above-mentioned statistical analysis reveals that the 24-item "The Gamification User Types Hexad Scale" was able to experimentally measure the user types of Marczewski, the subject of this study (Tondello et al., 2016).

\subsection{Data Collection Process}

Within the scope of the study, the information of 21 gifted children and their parents who were registered to the Children's University in the fall term of 2019-2020 were obtained from the Children's University registration system. During the same term, Parents of gifted children enrolled in the Children's University were given Gamification Education for 8 weeks. Gifted children and parents were asked to complete "The Gamification User Types Hexad Scale" to determine user types. It was decided to collect the data 
electronically for reasons such as low cost and time. However, the main reason for collecting data online is that the parents involved in the study are distributed in the context of space. After the analysis of the user types, it was gathered by interview forms about how parents' learning these user types had an effect on them.

\subsection{Data Analysis}

Frequency distributions, percentages, and descriptive statistics were used in the analyzes depending on the research questions.

\section{RESULTS}

Gifted children and parents were analyzed according to the scale of user types and their findings were presented.

Table 3. Distribution of gifted children and their parents, according to user types

\begin{tabular}{|l|l|l|l|}
\hline Family & Child & Mother & Father \\
\hline Family 1 & Achiever & Socialiser & Player \\
\hline Family 2 & Socialiser & Philanthropist & Achiever \\
\hline Family 3 & Socialiser & Philanthropist & Achiever \\
\hline Family 4 & Philanthropist & Philanthropist & Free Spirit \\
\hline Family 5 & Free Spirit & Socialiser & Philanthropist \\
\hline Family 6 & Socialiser & Free Spirit & Free Spirit \\
\hline Family 7 & Socialiser & Player & Philanthropist \\
\hline Family 8 & Philanthropist & Philanthropist & Philanthropist \\
\hline Family 9 & Philanthropist & Philanthropist & Philanthropist \\
\hline Family 10 & Achiever & Achiever & Socialiser \\
\hline Family 11 & Achiever & Free Spirit & Achiever \\
\hline Family 12 & Achiever & Philanthropist & Achiever \\
\hline Family 13 & Player & Socialiser & Free Spirit \\
\hline Family 14 & Achiever & Achiever & Socialiser \\
\hline Family 15 & Free Spirit & Player & Achiever \\
\hline Family 16 & Free Spirit & Free Spirit & Achiever \\
\hline Family 17 & Achiever & Philanthropist & Philanthropist \\
\hline Family 18 & Free Spirit & Socialiser & Philanthropist \\
\hline Family 19 & Philanthropist & Philanthropist & Player \\
\hline Family 20 & Free Spirit & Socialiser & Achiever \\
\hline Family 21 & Achiever & Socialiser & Philanthropist \\
\hline
\end{tabular}

In Table 3, families were analyzed separately as child, mother and father and the distributions regarding the type of users the families belong to are shown. Descriptive analyzes of these distributions are given in Table 4.

Table 4. Comparison of user types distributions of gifted children and parents

\begin{tabular}{|l|l|c|l|l|c|l|l|c|}
\hline \multicolumn{4}{|l|}{ User types of gifted children } & \multicolumn{3}{c|}{$\begin{array}{l}\text { User types of mothers of gifted } \\
\text { children }\end{array}$} & \multicolumn{2}{|c|}{$\begin{array}{c}\text { User types of fathers of } \\
\text { gifted children }\end{array}$} \\
\hline User Types & $\mathbf{F}$ & $\%$ & User Types & $\mathbf{F}$ & $\%$ & User Types & $\mathbf{F}$ & $\%$ \\
\hline Achiever & 7 & 33.34 & Philanthropist & 8 & 38.1 & Achiever & 7 & 33.34 \\
\hline Free Spirit & 5 & 23.81 & Socialiser & 6 & 28.58 & Philanthropist & 7 & 33.34 \\
\hline Philanthropist & 4 & 19.05 & Free Spirit & 3 & 14.29 & Free Spirit & 3 & 14.29 \\
\hline Socialiser & 4 & 19.05 & Achiever & 2 & 9.53 & Socialiser & 2 & 9.53 \\
\hline Player & 1 & 4.77 & Player & 2 & 9.53 & Player & 2 & 9.53 \\
\hline Total & $\mathbf{2 1}$ & $\mathbf{1 0 0}$ & Total & $\mathbf{2 1}$ & $\mathbf{1 0 0}$ & Total & $\mathbf{2 1}$ & $\mathbf{1 0 0}$ \\
\hline
\end{tabular}

When Table 4 is examined, user types of gifted children; 33.34\% Achiever $(n=7), 23.81 \%$ Free Spirit $(n=5)$, $19.05 \%$ Philanthropist $(n=4), 19.05 \%$ Socialiser $(n=4)$ and $4.77 \%$ Player $(n=1)$, user types of mothers of gifted children; $38.1 \%$ Philanthropist $(n=8), 28.58 \%$ Socialiser $(n=6), 14.29 \%$ Free Spirit $(n=3), 9.53 \%$ Achiever $(n=2), 9.53 \%$ Player $(n=2)$; user types of fathers of gifted children; $33.34 \%$ Achiever $(n=7), 33.34 \%$ Philanthropist $(n=7), 14.29 \%$ Free Spirit $(n=3), 9.53 \%$ Socialiser $(n=2), 9.53 \%$ determined as Player $(n=2)$. 
According to these results, it is concluded that gifted children are mostly Achiever and Free Spirit, mothers are Philanthropist and Socialiser and fathers are Achievers and Philanthropists. When the user types were examined, it was concluded that there were no Disruptors.

Table 5. Age distribution according to the state of gifted children's phones

\begin{tabular}{|c|c|c|c|c|c|c|c|c|c|c|}
\hline $\begin{array}{c}\text { Do you have a } \\
\text { phone? }\end{array}$ & $\begin{array}{c}\mathbf{6} \\
\text { Ages }\end{array}$ & $\begin{array}{c}\mathbf{7} \\
\text { Ages }\end{array}$ & $\begin{array}{c}\mathbf{8} \\
\text { Ages }\end{array}$ & $\begin{array}{c}\mathbf{9} \\
\text { Ages }\end{array}$ & $\mathbf{1 0}$ Ages & $\begin{array}{c}\mathbf{1 1} \\
\text { Ages }\end{array}$ & $\begin{array}{c}\mathbf{1 2} \\
\text { Ages }\end{array}$ & $\begin{array}{c}\mathbf{1 3} \\
\text { Ages }\end{array}$ & F & $\%$ \\
\hline Yes & - & - & 3 & 6 & 3 & 1 & 1 & 1 & $\mathbf{1 5}$ & $\mathbf{7 1 . 4 2}$ \\
\hline No & 1 & 1 & 3 & 1 & - & - & - & - & $\mathbf{6}$ & $\mathbf{2 8 . 5 8}$ \\
\hline Total & 1 & 1 & 6 & 7 & 3 & 1 & 1 & 1 & $\mathbf{2 1}$ & $\mathbf{1 0 0}$ \\
\hline
\end{tabular}

When Table 5 is examined, it is concluded that $71.42 \%$ of gifted children have their own phones $(n=15)$ and only $28.58 \%$ do not have a telephone $(n=6)$. The results of the research show that gifted children have phones from the age of 8 .

Table 6. User types according to the availability of computers in gifted children

\begin{tabular}{|c|l|c|c|c|c|c|c|c|c|c|c|c|}
\hline \multirow{2}{*}{$\begin{array}{c}\text { Do you have a } \\
\text { computer? }\end{array}$} & Achiever & \multicolumn{2}{c|}{$\begin{array}{c}\text { Free } \\
\text { Spirit }\end{array}$} & \multicolumn{2}{c|}{ Socialiser } & Philanthropist & \multicolumn{2}{|c|}{ Player } & \multicolumn{2}{|c|}{ Total } \\
\cline { 2 - 14 } & $\mathbf{F}$ & $\%$ & $\mathbf{F}$ & $\%$ & $\mathbf{F}$ & $\%$ & $\mathbf{F}$ & $\%$ & $\mathbf{F}$ & $\%$ & $\mathbf{F}$ & $\%$ \\
\hline Yes & 7 & 33.34 & 4 & 19.04 & 2 & 9.52 & 2 & 9.52 & 1 & 4.77 & 16 & 76.20 \\
\hline No & - & - & 1 & 4.77 & 2 & 9.52 & 2 & 9.52 & - & - & 5 & 23.80 \\
\hline Total & 7 & 33.34 & 5 & 23.81 & 4 & 19.04 & 4 & 19.04 & 1 & 4.77 & 21 & 100 \\
\hline
\end{tabular}

When Table 6 is examined, it is revealed that $76.20 \%$ of gifted children have computers $(n=16)$ and $23.80 \%$ of gifted children do not have computers $(n=5)$. 33.34\% $(n=7)$ of gifted children who have computers Achiever, 19.04\% $(n=4)$ Free Spirit, 9.52\% $(n=2)$ Socialiser, 9.52\% $(n=2)$ Philanthropist, $4.77 \%$ Player $(n=1)$ were determined to have user types. Socialiser $(n=2)$, Philanthropist $(n=2)$ and Free Spirit $(n=1)$ were found to have no computers.

Table 7. Distribution of user types according to parents playing digital games

\begin{tabular}{|c|c|c|c|c|c|c|c|c|c|c|c|c|c|}
\hline \multirow{2}{*}{ Parents } & \multirow{2}{*}{$\begin{array}{c}\text { Digital } \\
\text { gaming } \\
\text { situations }\end{array}$} & \multicolumn{2}{|c|}{ Philanthropist } & \multicolumn{2}{|c|}{ Achiever } & \multicolumn{2}{|c|}{ Socialiser } & \multicolumn{2}{|c|}{ Free Spirit } & \multicolumn{2}{|c|}{ Player } & \multicolumn{2}{|c|}{ Total } \\
\hline & & $\mathbf{F}$ & $\%$ & $\mathbf{F}$ & $\%$ & $\mathbf{F}$ & $\%$ & $\mathbf{F}$ & $\%$ & $\mathbf{F}$ & $\%$ & $F$ & $\%$ \\
\hline \multirow{2}{*}{ Mother } & Yes & 1 & 2.38 & - & - & 2 & 4.76 & 1 & 2.38 & - & - & 4 & 9.52 \\
\hline & No & 7 & 16.66 & 2 & 4.76 & 4 & 9.52 & 2 & 4.76 & 2 & 4.76 & 17 & 40.48 \\
\hline \multirow{2}{*}{ Father } & Yes & 1 & 2.38 & - & - & 1 & 2.38 & 1 & 2.38 & 1 & 2.38 & 4 & 9.52 \\
\hline & No & 6 & 14.28 & 7 & 16.66 & 1 & 2.38 & 2 & 4.76 & 1 & 2.38 & 17 & 40.48 \\
\hline \multicolumn{2}{|c|}{ Total } & 15 & 35.71 & 9 & 21.42 & 8 & 19.04 & 6 & 14.28 & 4 & 9.52 & 42 & 100 \\
\hline
\end{tabular}

In Table 7, the status of the digital gameplay of the parents was determined and compared with the results of the user types. $40.48 \%$ of the mothers $(n=17)$ and $40.48 \%$ of the fathers $(n=17)$ were found not to play digital games, while $9.52 \%$ of the mothers played $(n=4)$ and likewise $9.52 \%$ of the fathers $(n=4)$ were found to play games. $16.66 \%$ of mothers who did not play digital games were Philanthropists $(n=7), 9.52 \%$ were Socialiser $(n=4), 16.66 \%$ of the fathers who did not play digital games were Achiever $(n=7)$ and $14.28 \%$ were found to be a Philanthropist $(n=6)$.

Table 8. Distribution of user types according to the games most preferred by gifted children

\begin{tabular}{|l|c|c|c|c|c|}
\hline $\begin{array}{l}\text { Gifted children's preferred } \\
\text { games }\end{array}$ & Achiever & Free Spirit & Philanthropist & Socialiser & Player \\
\hline Educational Games & 7 & & & & \\
\hline Adventure games & & 3 & & & \\
\hline Simulation Games & & & 4 & & \\
\hline Strategy games & & 2 & & & \\
\hline Sports Games & & & & 1 \\
\hline Racing Games & & & & 4 & \\
\hline
\end{tabular}

According to Table 8, the most preferred games by gifted children are given and the types of users of these children are analyzed. It was determined that children who play educational games have Achiever $(n=7)$, playing adventure games $(n=3)$ and strategy games have Free Spirit $(n=2)$, playing simulation games has 
Philanthropist $(n=4)$ user types. It was determined that children who play racing games have Socialiser $(n=4)$, playing sports games have the Player $(n=1)$ user types.

The parents who participated in the analysis were asked, "How did learning your user types affect you?" research question for opinions were determined and asked. Content analysis was performed on the data obtained. The themes identified as a result of this analysis are given in Table 9.

Table 9. "How did learning your user types affect you?" themes of the research question

\begin{tabular}{|l|c|c|}
\hline Themes & F & $\%$ \\
\hline I realized the sources of motivation, according to user types & 16 & 38.10 \\
\hline I understood why my child is not motivated by other gameplay elements & 14 & 33,33 \\
\hline I have learned the elements of gamification that my child can motivate & 12 & 28.57 \\
\hline Total & $\mathbf{4 2}$ & $\mathbf{1 0 0}$ \\
\hline
\end{tabular}

After the user type analysis, the views of the parents were gathered under three themes. These themes are "I realized the sources of motivation, according to user types", "I understood why my child is not motivated by other gameplay elements", and "I have learned the elements of gamification that my child can motivate". Under these themes, it was revealed how the parents expressed their views on the gamification elements that motivated the user types according to the user type analysis.

The parent who says he/she is aware of motivation sources, according to user types (Mother 18): 'We learned detailed information about motivation sources, according to user types and we learned that our motivation sources change according to user types' and he said that motivation elements change according to user types. Another parent who has similar views; 'We noticed that the motivation elements are different for each person, the motivational tests and the types of user we learned at the end of the tests.' (Mother 3 ) and stated that they become aware of the sources of motivation that they can be motivated by.

Parents who understand why their child is not motivated by other play elements (Father 14): "It made me go down to my child's point of view. I realized the motivation that would make him happy. I realized that their intrinsic motivation should be strengthened."He stated that his child is not motivated by other gamification elements and becomes aware of the sources of motivation according to user types.

A parent who has learned the gamification elements that his/her child can be motivated (Father 8): "It was important to me to identify user types and to learn motivation sources based on my child's character." $\mathrm{He}$ said that he learned the resources that motivate his child. A similar opinion of another parent; "It was very useful for my child and us to learn the effects of motivation elements on people and to compare them with user types." (Father 20).

\section{CONCLUSIONS}

When the results of the study were examined, it was found that gifted children were mostly Achiever and Free Spirit, with intrinsic motivation at the forefront. Mothers were found to be mostly Philanthropists and Socialiser. Fathers were founded to be mostly Achievers and Philanthropists. When the player/user types were examined, it was concluded that there were no Disruptors. The study was conducted by Tondello et al. (2016) developed by "The Gamification User Types Hexad Scale". It can be said that it confirms the findings of the study. Tondello et al. (2016) in the study of Philanthropists, Free Spirits and Achievers have averaged close to each other; Socialisers and Players have followed these user types. The lowest average user type in the research is the Disruptors. A similar study was conducted by Şenocak (2019). According to the results of the research, the most common user types in Open and Distance Learning environments were found to be Philanthropists, Achievers, and Free Spirit, and Socialisers and Players followed these users with less average and the least seen user types were Disruptors (Şenocak, 2019).

In parallel with Marczewski's results (2018), Free Spirit, Achievers, and the Philanthropists were identified as common user types in this study, and the Socialiser' follow up of the other user type averages suggests that the basic psychological needs advocated by the Self-Determination Theory and the desire to meet these needs are strong sources of motivation for the systems to be enacted.

In this study, it was concluded that there are no Disruptors. In this kind of research, Disruptors were found to have the least average. In a different study, Disruptors were found to be the lowest average user type, while other user types were found to have the highest average. The findings of the study are also the most common of Philanthropists; It also supports the study of Fischer, Heinz, and Breitenstein (2018), which is the least prevalent of Disruptors.

The results of the study revealed that gifted children have phones from the age of 8 . It was also concluded that the majority of gifted students had computers. It was determined that the majority of those who had 
computers were Achiever and Free Spirit and those without computers were Socialiser and Philanthropist. It was concluded that the majority of parents did not play digital games. Mothers who do not play digital games are identified as Philanthropists, Socialiser, and fathers who do not play digital games are Achievers and Philanthropists.

Most preferred games of gifted children; Educational games, Adventure games, Simulation games, Strategy Games, Racing and Sports games. It was determined that children who play educational games have Achiever, playing adventure games and strategy games have Free Spirit, playing simulation games have Philanthropist user types. It was determined that children who play racing games have Socialiser, playing sports games have Player user types. However, other research findings have been examined according to the Rehabilitation Game Model of five popular commercial games and three rehabilitation games, supporting the emphasis of all game genres, particularly on the intrinsically motivated Achievers. (Holmes, Charles, Morrow, McClean, \& McDonough, 2015).

When the opinions of the parents regarding the user type analysis were examined, it was determined that they expressed their opinions under three themes. Parents stated that they were aware of the sources of motivation, according to the user types, that they understand why their child is not motivated by other gamification elements and that they have learned the gamification elements that their child can be motivated. These findings suggest that different game mechanics used in gamification motivate individuals in different directions (Orji, Mandryk, Vassileva, \& Gerling, 2013) and that individual gamification system that can be customized for each individual can have a more positive effect on motivation (van Roy \& Zaman, 2015; Paiva, Bittencourt, Tenório, Jaques, \& Isotani, 2016; Jang, Park, \& Mun, 2015).

As a suggestion; Studies should be conducted to examine the relationship between user types and motivating game elements, their distribution or persuasion strategies, and the relationship between these user types and academic achievement.

\section{REFERENCE LIST}

Ames, C. (1992). Classrooms: Goals, Structures, and Student Motivation. Journal of Educational Psychology, 84 (3), 261-271.

Bayraktar, S. (2001). A meta-analysis of the effectiveness of computer-assisted instruction in science education. Journal of research on technology in education, 34(2), 173-188.

Blackburn, A. C., \& Erickson, D. B. (1986). Predictable crises of the gifted student. Journal of Counseling \& Development, 64 (9), 552-555.

Çakmak, M., \& Ercan, L. (2006). Views of experienced and student teachers about motivation in effective teaching process. Gazi Eğitim Fakültesi Dergisi, 26(3), 133-143.

Deterding, S. (2012). Gamification: designing for motivation. Interactions, 19(4), 14-17.

Deterding, S., Dixon, D., Khaled, R., \& Nacke, L. (2011, September). From game design elements to gamefulness: defining gamification. In Proceedings of the 15th international academic MindTrek conference: Envisioning future media environments (pp. 9-15). ACM.

Ersen, H., (1997). Toplam Kalite ve İnsan Kaynakları İlişkisi Verimlilik ve Etkin Olmanın Yolu. İstanbul.

Fischer, H., Heinz, M., \& Breitenstein, M. (2018, October). Gamification of Learning Management Systems and User Types in Higher Education. In ECGBL 2018 12th European Conference on Game-Based Learning (p. 91). Academic Conferences and publishing limited.

Fogg, B. J. (2009, April). A behavior model for persuasive design. In Proceedings of the 4th international Conference on Persuasive Technology (p. 40). ACM.

Freeman, J. (2003). Gender differences in gifted achievement in Britain and the US. Gifted Child Quarterly, 47(3), 202-211.

Freeman, J. (2004). Teaching the gifted and talented. Education Today-London-College of Preceptors Then College of Teachers-, 54(3), 17-21.

Hamari, J. (2013). Transforming Homo Economicus into Homo Ludens: A Field Experiment on Gamification in a Utilitarian Peer-To-Peer Trading Service. Electronic Commerce Research and Applications, 12(4), pp. 236-245. 
Holmes, D., Charles, D., Morrow, P., McClean, S., \& McDonough, S. (2015, October). Rehabilitation game model for personalised exercise. In 2015 International Conference on Interactive Technologies and Games (pp. 41-48). IEEE.

Jang, J., Park, J. J., \& Mun, Y. Y. (2015). Gamification of online learning. In International Conference on Artificial Intelligence in Education (pp. 646-649). Cham: Springer.

Marczewski, A. (2015). User Types. In Even Ninja Monkeys Like to Play: Gamification, Game Thinking and Motivational Design (1st ed., pp. 65-80). Create Space Independent Publishing Platform

Marczewski, A. (2018). HEXAD: A Player Type Framework for Gamification Design. https://www.gamified.uk/user-types/ (Erişim Tarihi: 4.11.2018).

MEB (2001). Bilim ve Sanat Merkezleri Yönergesi. Ankara.

Orji, R., Mandryk, R. L., Vassileva, J., \& Gerling, K. M. (2013, April). Tailoring persuasive health games to gamer type. In Proceedings of the SIGCHI Conference on Human Factors in Computing Systems (pp. 2467-2476). Paris, France.

Paiva, R., Bittencourt, I. I., Tenório, T., Jaques, P., \& Isotani, S. (2016). What do students do on-line? Modeling students' interactions to improve their learning experience. Computers in Human Behavior, 64, 769-781.

Renzulli, J.S. (1986). The three-ring conception of giftedness: A developmental model for creative productivity. In R. J. Sternberg \& J. Davidson (Eds.), Conceptions of giftedness (pp. 53-92). Cambridge: University of Cambridge.

Risemberg, R., \& Zimmerman, B. J. (1992). Self-regulated learning in gifted students. Roeper Review, 15(2), 98-101.

Ryan, R. M., Rigby, C. S., \& Przybylski, A. (2006). The motivational pull of video games: A self-determination theory approach. Motivation and emotion, 30(4), 344-360.

Sak, U., \& Maker, C. J. (2005). Divergence and convergence of mental forces in open and closed mathematical problems. International Education Journal, 6(2), 252-260.

Şenocak, D. Açık ve uzaktan öğrenmede oyuncu tiplerinin motivasyon ve akademik başarı bağlamında incelenmesi.

Tondello, G. F., Mora, A., Marczewski, A., \& Nacke, L. E. (2018). Empirical Validation of the Gamification User Types Hexad Scale in English and Spanish. International Journal of Human-Computer Studies. Doi:https://doi.org/10.1016/j.ijhcs.2018.10.002

Tondello, G. F., Wehbe, R. R., Diamond, L., Busch, M., Marczewski, A., \& Nacke, L. E. (2016, October). The gamification user types hexad scale. In Proceedings of the 2016 annual symposium on computerhuman interaction in play (pp. 229-243). ACM.

Torrance, E. P., \& Goff, K. (1989). A quiet revolution. The journal of creative behavior, 23(2), 136-145.

van Roy, R., \& Zaman, B. (2015, October). The inclusion or exclusion of teaching staff in a gamified system: an example of the need to personalize. In Workshop on Personalization in Serious and Persuasive Games and Gamified Interactions. London, UK.

VanTassel-Baska, J. (1994). Comprehensive curriculum for gifted learners. Allyn \& Bacon.

Werbach, K., \& Hunter, D. (2012). For the win: How game thinking can revolutionize your business. Wharton Digital Press.

Wild, T. C., Enzle, M. E., \& Hawkins, W. L. (1992). Effects of perceived extrinsic versus intrinsic teacher motivation on student reactions to skill acquisition. Personality and social psychology bulletin, 18(2), 245-251.

Winebrenner, S. (2003). Teaching strategies for twice-exceptional students. Intervention in school and clinic, 38(3), 131-137.

Winebrenner, S., \& Brulles, D. (2008). The cluster grouping handbook: A schoolwide model: How to challenge gifted students and improve achievement for all. Free Spirit Publishing.

Zichermann, G., \& Cunningham, C. (2011). Gamification by design: Implementing game mechanics in web and mobile apps. " O'Reilly Media, Inc.". 